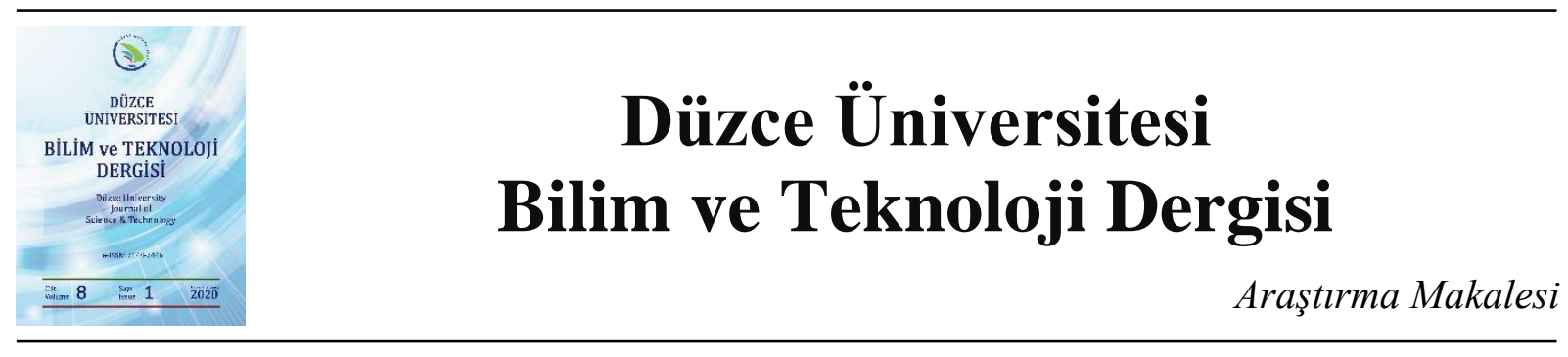

\title{
Düzce İli Kalıcı Konutlar Bölgesindeki Spor Alanlarının Yeterliliğinin İrdelenmesi
}

\author{
Tayfun ÇEBİ ${ }^{\mathrm{a}, *}$, (D) Zeki DEMIR ${ }^{\mathrm{a}}$ \\ a Peyzaj Mimarlığı Bölümü, Orman Fakültesi, Düzce Üniversitesi Düzce, TÜRKIYYE \\ * Sorumlu yazartn e-posta adresi: tayfun-cebi6181@ hotmail.com
}

DOI: 10.29130/dubited.583760

\begin{abstract}
ÖZET
Bu çalışmada; Düzce ili, merkez ilçesinde bulunan kalıcı konutlar bölgesinde yer alan mahallerde bulunan spor alanlarının yerleri, ulaşa bilirlikleri, fiziki durumları, büyüklük ve faaliyet alanları belirlenerek, olması gereken standartlara uygunluğu analiz edilmiştir. Düzce ili merkez ilçesinde bulunan kalıcı konutlar bölgesi 661.978,57 $\mathrm{m}^{2}$ lik yeşil alan yer almaktadır. Bu yeşil alan içerisinde bulunan park alanı 508.947,20 $\mathrm{m}^{2}$ olarak hesaplanmıştır. Yeşil alanları içeriğinde mezarlıklar, orman alanları, çocuk oyun alanları, meydanlar, ağaçlandırma alanı ve spor alanları bulunmaktadır. Kalıcı konutlarda yer alan 6 adet mahallerde nüfus, 31 Aralık 2017 tarihli ADNKS (Adrese dayalı nüfus kayıt sistemi) nüfus sayım sonuçlarına göre; \%52,59'si kadın, \%47,41'si erkek olmak üzere çalışma alanında nüfusu sayısı 23.219 'dur. Ülkemizde kentlerin planlama sürecini, yeşil alanlara yönelik yaklaşımı, kişi başına belirli büyüklükte yeşil alanın ayrılmasını sağlayan yasal mevzuat, imar yönetmelikleri ve imar planlarıdır. Türkiye'deki kentler için 02.09.1999 tarih ve 23804 sayılı Resmî Gazete'de yayımlanan 'İmar Planı Yapılması ve Değişikliklerine Ait Esaslara Dair Yönetmelik' hükümlerine göre; kentsel alanlarda kişi başına düşen yeşil alan değeri en az $10 \mathrm{~m}^{2}$ ve bu yeşil alanın komşuluk ünitesi düzeyinde dağ $1 ı \mathrm{~m} ı 1.5 \mathrm{~m}^{2} / \mathrm{kişi} \mathrm{çocuk} \mathrm{oyun} \mathrm{alanı,} 2 \mathrm{~m}^{2} / \mathrm{kişi}$ mahalle ve semt parkı, $3 \mathrm{~m}^{2} /$ kişi spor alanı ve $3.5 \mathrm{~m}^{2} / \mathrm{kişi} \mathrm{kent} \mathrm{parkı} \mathrm{olması} \mathrm{gereklidir.} \mathrm{Böylece} \mathrm{yasal} \mathrm{mevzuata}$ göre, kişi başına $3,00 \mathrm{~m}^{2}$ spor alanlarına ihtiyaç olduğu belirtilmiştir. Çalışma alanının mevcut nüfusu dikkate alındığında çalışma alanının planlama standartlarına uygun spor alanı ihtiyacı $69.657,00 \mathrm{~m}^{2}$ dir. Çalışma sonucunda kalıcı konutlarda $15.349,00 \mathrm{~m}^{2}$ mevcut spor alanı ve 54.304,00 $\mathrm{m}^{2}$ spor alanını eksikliği hesaplanmıştır. Sonuçta, çalışma alanındaki mevcut spor alanları şu anki fiziki durumları, donatısal yeterlilikleri, büyüklükleri ve faaliyet alanları olması gereken spor alanı miktarı açısından değerlendirmeye alındığında eksiklikler olduğu görülmüştür. Çalışma sonunda; çalışma alanında bulunan spor alanlarının etkinliğinin artırılması için öneriler geliştirilmiştir.
\end{abstract}

Anahtar Kelimeler: Açık ve yeşil alanlar, Spor alanları, Düzce, Kalıcı Konutlar

\section{Study of the Adequacy of Sports Areas in the Kalıc1 Konutlar Region of Duzce City}

\begin{abstract}
In this study; the locations, accessibility, physical conditions, size and activity areas of the sports areas located in the 6 districts of Kalıcı Konutlar region of Düzce province were determined and their compliance with the required standards were analyzed. There are 661.978,57 $\mathrm{m}^{2}$ green area in the Kalıcı Konutlar region located in Düzce municipality. The park area within this green area is determined as $508.947,20 \mathrm{~m}^{2}$. Green areas include graveyards, forest areas, children's playgrounds, squares, afforestation area and sports areas. The population in the 6 districts located in the Kalıc1 Konutlar region, according to the census results of the "ADNKS" (Address Based Population Registration System) dated December 31, 2017; 52.59\% women, 47.41\% male population in the study area, with total number of 23.219. In our country, the planning process of the cities, the green area approach, the legislative
\end{abstract}


regulations that provide the separation of the green area per capita are the zoning regulations and development plans. According to the provisions in "Regulations of Principles about Development Plans and Amendments" published in the Official Gazette No. 23804 on 02.09.1999; the green land per capita in urban areas required to be at least $10 \mathrm{~m}^{2}$ and the distribution of this green land at the neighborhood unit level is $1.5 \mathrm{~m}^{2}$ per capita for children playground, $2 \mathrm{~m}^{2}$ per capita for neighborhood and district park, $3 \mathrm{~m}^{2}$ per capita for sports field and $3.5 \mathrm{~m} 2$ per capita for urban park. Thus, according to the legal regulations, it is stated that $3,00 \mathrm{~m}^{2}$ of sports areas per capita is needed. Considering the current population of the study area, the required size of the sports field in accordance with the planning standards of the study area is $69.657,00 \mathrm{~m}^{2}$. Because of the study, $15.349,00 \mathrm{~m}^{2}$ of existing sports area and 54.304,00 $\mathrm{m}^{2}$ of required sports area in the Kalıc1 Konutlar region was calculated. As result, existing sports areas in the study area were found to be insufficient when the current physical conditions, qualifications, size and activity areas of the reinforcement elements were evaluated in terms of the standards. As the result of the study recommendations have been developed to overcome the insufficent conditions that has been seen and to increase the efficiency of the sports fields in the study area.

Keywords: Open and green land, Sport field, Düzce, Kalıcı Konutlar

\section{GIRIS}

Açık alan tanımı, Mimari yapı ve ulaşım alanları kenttin temel elemanlarıdır. Bu alanların dışında kalan boş alanlar veya açıklıklar olarak ifade edilmektedir. Diğer bir ifadeyle, dış mekanda herhangi bir amaca göre yapılaşmanın olmadığı ve herhangi bir rekreasyonel kullanımı için uygun potansiyel imkanı bulunan alanlar olarak algilanmaktadır [1], [2].

Yeşil alan tanımı,23804 sayılı İmar Yönetmeliğinde, “Toplumun faydalanabilmesi için ayrılan çocuk ve oyun bahçeleri, dinlenme, gezinti, kıyı, piknik ve eğlence alanlarının bütünüdür. İnterpol ölçekteki botanik ve hayvanat bahçeleri, bölgesel parklar ve fuar alanları ve bölgesel parklar yeşil alan içerisinde bulunmaktadır. "şeklinde ifade edilmektedir. Aktif açık yeşil alan tanımı ise çocuk bahçesi, mahalle ve kent parkı, oyun alanlarının toplamı olarak ifade edilmektedir [3].

Türkiye'de ilk defa 1933-1956 yılları arasında 2290 sayılı Yap1 Yolları Konunu ile kent düzenleme planlarında kişi başı yeşil alan $4 \mathrm{~m}^{2}$ normu önerilmiştir. Önerilen yeşil alan içerisinde koru, çayır, göl ve oyun alanlarını bulundurmaktadır. Bu hüküm 1956 yılında İmar Kanunu ile kaldırılmıştır. Bu hükmün yerine 6785/1605 sayılı İmar Kanunun 28. maddesinde en az toplam $7 \mathrm{~m}^{2}$ kişi başına düşen açık-yeşil alan öngörülmüştür. Yeşil alan içeriğinde kent parkları $1,5 \mathrm{~m}^{2}$, kent düzeyinde semt stadı $1 \mathrm{~m}^{2}$, mahalle parkları $1 \mathrm{~m}^{2}$, mahalle düzeyinde oyun ve spor alanları (11-18 yaş) $2 \mathrm{~m}^{2}$, komşuluk düzeyinde oyun ve çocuk bahçeleri (3-6 ile 7-11 yaş) 1,5 m²'lik alanlara sahiptir [4].

Türkiye'de yeşil alanlar 3194 sayılı imar Kanunu içerisinde belirtilmektedir.1985 y1lında kişi başına düşen yeşil alan $7 \mathrm{~m}^{2}$ iken 1999 yılında yönetmelik değişikliği yapılarak asgari kişi başına düşen yeşil alan miktarı $10 \mathrm{~m}^{2}$ değerine yükseltilmiştir. Türkiye'de yeşil alan içeriğinde kent parkları $3,5 \mathrm{~m}^{2}$, mahalle semt parkı $2 \mathrm{~m}^{2}$, çocuk oyun alanı $1,5 \mathrm{~m}^{2}$ ve spor alanı $3 \mathrm{~m}^{2}$ lik alanlara sahiptir.

Tablo1. Dünya ülkelerinden yeşil alan standartları ( $\left.\mathrm{m}^{2} / k i s ̧ i\right)$ (Aksoy, 2001).

\begin{tabular}{lllllll} 
Ülkeler & $\begin{array}{l}\text { Kent } \\
\text { YakınıeşilZo } \\
\mathbf{n}\left(\mathbf{m}^{2}\right)\end{array}$ & $\begin{array}{l}\text { Kent Parkı } \\
\left(\mathbf{m}^{\mathbf{2}}\right)\end{array}$ & $\begin{array}{l}\text { Mahalle/Semt } \\
\text { Parkı }\left(\mathbf{m}^{\mathbf{2}}\right)\end{array}$ & $\begin{array}{l}\text { ÇocukOyun } \\
\text { Alanı }\left(\mathbf{m}^{\mathbf{2}}\right)\end{array}$ & $\begin{array}{l}\text { SporAlanı } \\
\left(\mathbf{m}^{\mathbf{2}}\right)\end{array}$ & $\begin{array}{l}\text { Toplam } \\
\left(\mathbf{m}^{\mathbf{2}}\right)\end{array}$ \\
\hline İşveç & 48,1 & 23,8 & - & 5,6 & 10 & 87,5 \\
\hline Amerika & 60 & $13-20$ & 3,9 & - & - & $77-84$ \\
\hline İngiltere & 8 & 40 & 20 & - & 10 & 78 \\
\hline İtalya & 18 & 11,6 & 5,5 & 3,2 & 7,5 & 45,8 \\
\hline Fransa & 10 & 10 & 4,2 & 3,5 & 8 & 35,7 \\
\hline Türkiye & - & $\mathbf{3 , 5}$ & $\mathbf{2}$ & $\mathbf{1 , 5}$ & $\mathbf{3}$ & $\mathbf{1 0}$
\end{tabular}


Tablo1'de bahse edilen ülkelerden kişi başına düşen toplam yeşil alan miktarı ile en fazla İsveç $(87,5$ $\mathrm{m}^{2} /$ kişi) iken, en az değer ise Türkiye $\left(10 \mathrm{~m}^{2} /\right.$ kişi)'dedir. Kent parkı bahse edilen ülkelerde kişi başına düşen miktar İngiltere'de $40 \mathrm{~m}^{2}$ ile en fazla alana sahipken en az miktar $3,5 \mathrm{~m}^{2}$ ile Türkiye'ye aittir.

Tablo 2. Parkların Standartlart

\begin{tabular}{cccccc} 
Parklar & $\begin{array}{c}\text { Etkili } \\
\text { Hizmet } \\
\text { Alanı } \\
\text { (Yarı̧ap) }\end{array}$ & $\begin{array}{c}\text { Kullanıcıların Yaş } \\
\text { Grubu (Yaş) }\end{array}$ & $\begin{array}{c}\text { Kişi Başına } \\
\text { Büyüklük } \\
\text { (dekar/1000kişi) }\end{array}$ & $\begin{array}{c}\text { Hizmet Ettiği } \\
\text { Nüfus } \\
\text { (Kişi) }\end{array}$ & $\begin{array}{c}\text { İdeal } \\
\text { Büyüklük } \\
\text { (dekar) }\end{array}$ \\
\hline Çocuk Bahçeleri & $\begin{array}{c}200- \\
600 \mathrm{~m}\end{array}$ & $0-3,4-7,8-15$ & 4 & $8-16$ \\
\hline Spor Alanları & $\mathbf{2 k m}$ & $\mathbf{7 ~ v e ~ y u k a r ı s ı ~}$ & $\mathbf{4}$ & Bütün Kent & $\mathbf{4 0 - 6 0}$ \\
\hline Mahalle Parkları & $\begin{array}{c}500- \\
1.500 \mathrm{~m}\end{array}$ & Bütün Yaşlar & $8-12$ & $3.500-5.000$ & $20-40$ \\
\hline Semt Parkları & $\begin{array}{c}1.000- \\
2.500 m\end{array}$ & Bütün Yaşlar & $10-20$ & $15.000-30.000$ & $160-400$ \\
\hline Kent Parkları & $1-10 \mathrm{~km}$ & Bütün Yaşlar & 80 & Bütün Kent & $40-800$ \\
\hline Bölge Parkları & $\begin{array}{c}25- \\
100 \mathrm{~km}\end{array}$ & Bütün Yaşlar & $750-3.000$ & & $2.000-4.000$ \\
\hline Milli Parkları & $\begin{array}{c}\text { Bütün } \\
\text { Ülke }\end{array}$ & Bütün Yaşlar & Değişken & Bütün Ülke & Değişken \\
\hline
\end{tabular}

Kaynak: (Tümer 1976[6], Ylldızcı 1982[7], Bakan ve Konuk 1987[8], Türel1988[9]

Aynı zamanda İngiltere'de kişi başına düşen mahalle ve semt parkı $20 \mathrm{~m}^{2}$ ile en fazla alana sahipken ülkemizde bu miktar $2 \mathrm{~m}^{2}$ dir. Bahsedilen ülkelerden kişi başına düşen spor alanları ise İsveç ve İngiltere'de $10 \mathrm{~m}^{2}$ ile en fazla değere sahipken Türkiye'de kişi başına düşen spor alanları $3 \mathrm{~m}^{2}$ ye sahiptir. Yeşil alanların türleri, kapsamları, faaliyetleri ve büyüklüklerini belirleyen etmenler vardır. Etmenler başında yerleşim yerinin nüfusuna, fiziksel(topoğrafya, toprak kabiliyet vb.),doğal (iklim, bitki örtüsü vb.) özeliklerine göre değişiklik göstermektedir [5].Park alanları için ihtiyaç duyulan standartlar; etki ettiği nüfus, kettin büyüklüğü, etki ettiği hizmet alanı, coğrafi konumu, iklim, bitki örtüsü ve yoğunluğu ile açıklanabilir. Polat (2002), Tablo 2 ve Tablo 3 'te standartları gösteren değişiklikler ifade edilmiştir. Tablolarda sayısal büyüklük ve konum, tesis ve faaliyetler açısından standartlar yer almaktadır.

Tablo 3. Parklar, Konum, Tesis ve Faaliyetler Açısından Standartları

PARKLAR KONUM TESIS VE FALIYYETLER

Çocuk Konut alanları içinde ana ulaşım Çocukların yaşlarına uygun yeteneklerinin

Bahçeleri ağı dışında oto trafiğinin yoğun geliştirilmesine kolaylık sağlayan, oyun olmadığı yerlerde konutlardan etkinliklerine katılabilmelerini sağlayan, oyun rahatça izlenebilir olmalıdır elemanları, kum havuzları ve bitki örtüsüyle çevrilmiş alanlardır. Amaç olarak koordinasyon, denge, organ ve duyuları geliştirmektedir.

\begin{tabular}{|c|c|c|}
\hline $\begin{array}{l}\text { Spor } \\
\text { Alanları }\end{array}$ & $\begin{array}{l}\text { Kent çevresinde ulaşım ağına } \\
\text { yakın düzlük ve temiz hava } \\
\text { akımları olan alanlar tercih } \\
\text { edilmelidir. }\end{array}$ & $\begin{array}{l}\text { Amatör ve profesyonel spor faaliyetlerinin } \\
\text { (futbol, basketbol, voleybol, tenis, hentbol, boks, } \\
\text { dış mekan fitness aletleri, atıcılık, yelken ve } \\
\text { kayı, binicilik ve yüzme vb.) çalışma ve } \\
\text { müsabakalarının yapıldığı kapalı veya açık } \\
\text { tesislerdir. }\end{array}$ \\
\hline
\end{tabular}


Tablo 3. (devam) Parklar, Konum, Tesis ve Faaliyetler Açısından Standartları

\begin{tabular}{|c|c|c|}
\hline $\begin{array}{l}\text { Mahalle } \\
\text { Parkları }\end{array}$ & $\begin{array}{l}\text { Doğal özellik gösteren, ulaşım } \\
\text { ağına yakın ve konut } \\
\text { yoğunluğunu azaltacak bir } \\
\text { yerde olmalıdır. }\end{array}$ & $\begin{array}{l}\text { Küçük çapta piknik alanı, çay bahçesi, yürüme yolu, } \\
\text { bisiklet yolu ve çocuk bahçesi gibi tesisleri içinde } \\
\text { barındıran parklardır. }\end{array}$ \\
\hline $\begin{array}{l}\text { Semt } \\
\text { Parkları }\end{array}$ & $\begin{array}{l}\text { Kentin doğal mikro klima } \\
\text { özelliğini gösterir konumda } \\
\text { olmalı ve park içi oto trafiği } \\
\text { kısıtlı tutulmalıdır. }\end{array}$ & $\begin{array}{l}\text { Mahalle parklarındaki ek olarak, botanik bahçesi, } \\
\text { kültür merkezleri, müze, kütüphane, spor alanları, } \\
\text { arberetum, balık tutma vb. gibi tesisleri içeren ve } \\
\text { mahalle kümelerine hizmet eden parklardır. }\end{array}$ \\
\hline $\begin{array}{l}\text { Kent } \\
\text { Parkları }\end{array}$ & $\begin{array}{l}\text { Topoğrafik yönden çeşitlilik } \\
\text { gösteren doğal alanlar seçilmeli } \\
\text { kolay ulaşım sağlanmalıdır. } \\
\text { Ulaşım ağı Park içerisinden } \\
\text { geçebilir. }\end{array}$ & $\begin{array}{l}\text { Semt parklarına ek olarak fuar alanları, hayvanat } \\
\text { bahçesi, spor ve konser salonları, at patikaları vb. } \\
\text { tesisleri içerir. Kentin tümüne hizmet eden park } \\
\text { olmasının yanında kenttin açık yeşil alan dokusunu } \\
\text { belirler. }\end{array}$ \\
\hline $\begin{array}{l}\text { Bölge } \\
\text { Parkları }\end{array}$ & $\begin{array}{l}\text { Doğal özellik gösteren, mevcut } \\
\text { su kaynağı olan ve kolay ulaşım } \\
\text { imkanı olmakla birlikte daha } \\
\text { güzel yerler tercih edilmelidir. }\end{array}$ & $\begin{array}{l}\text { Daha uzun tatillerde kalınabileceği gibi hafta sonu } \\
\text { tercih edilen alanlardır. Bu alanlarda kış sporları bu } \\
\text { alan içerisinde yapılabilir. }\end{array}$ \\
\hline $\begin{array}{l}\text { Milli } \\
\text { Parklar }\end{array}$ & $\begin{array}{l}\text { Ekolojik özellik gösterirler. Yer } \\
\text { bakımından ender doğal } \\
\text { yerlerdir. }\end{array}$ & $\begin{array}{l}\text { Özellikleri korumaya yönelik olup yoğun şekilde } \\
\text { kullanıma açılmaz., yüzme, kamp yapma, balık } \\
\text { tutma, ata binme, yürüyüş, gibi faaliyetler } \\
\text { yapılmaktadır. }\end{array}$ \\
\hline
\end{tabular}

Kaynak: (Tümer 1976[6], Yıldızcı 1982[7], Bakan ve Konuk 1987[8], Türel1988[9]

\section{MATERYAL ve METOT}

Bu çalışma; birbiriyle ilişkili üç aşamada yürütülmüştür. Araştırmanın ilk aşamasında, çalışma konusuna ait veri toplamak amacıyla konuyla ilgili daha önceden yapılmış araştırma, makale, tez, kitap ve internet dokümanları incelenmiştir. Basit bir ifadeyle çalışma konusuyla ilgili veri toplanmıştır. Bu doğrultuda kentteki açık yeşil alanları, park alanları, aktif kullanılmakta olan park alanları ve spor alanlarına ilişkin veriler; Düzce Belediye Başkanlığı Park ve Bahçeler Müdürlügü Park ve Bahçeler biriminden; İmarla ilgili veriler ise Düzce Belediye Başkanlığı İmar ve Şehircilik Müdürlügü̆’nden, nüfusa ilişkin veriler ise Devlet İstatistik Enstitüsü ADNKS (Adrese dayalı nüfus kayıt sistemi)elde edilmiştir. Araştırmada Düzce Belediye Başkanlığa ait spor alanlanı ele alınmıştır. Aynı zamanda elde edilen veriler doğrultusunda park ve spor alanlarına gidilerek yerinde gözlem ve ölçüm yapılmıştır. İkinci aşamada ise, toplanan verilerle Düzce il merkezi kalıcı konutlar bölgesinde bulunan spor alanlarının; konumu, mevcut halleri, genel özellikleri, ulaşılabilirliği, bu alanların fiziksel yeterliliği; alan, büyüklükleri ve faaliyet alanları açısından analiz edilmiştir. Üçüncü aşamada ise analizler sonucu olumlu ve olumsuz değerlendirmeler yapılıp gerekli öneriler getirilerek tamamlanmıştır. 


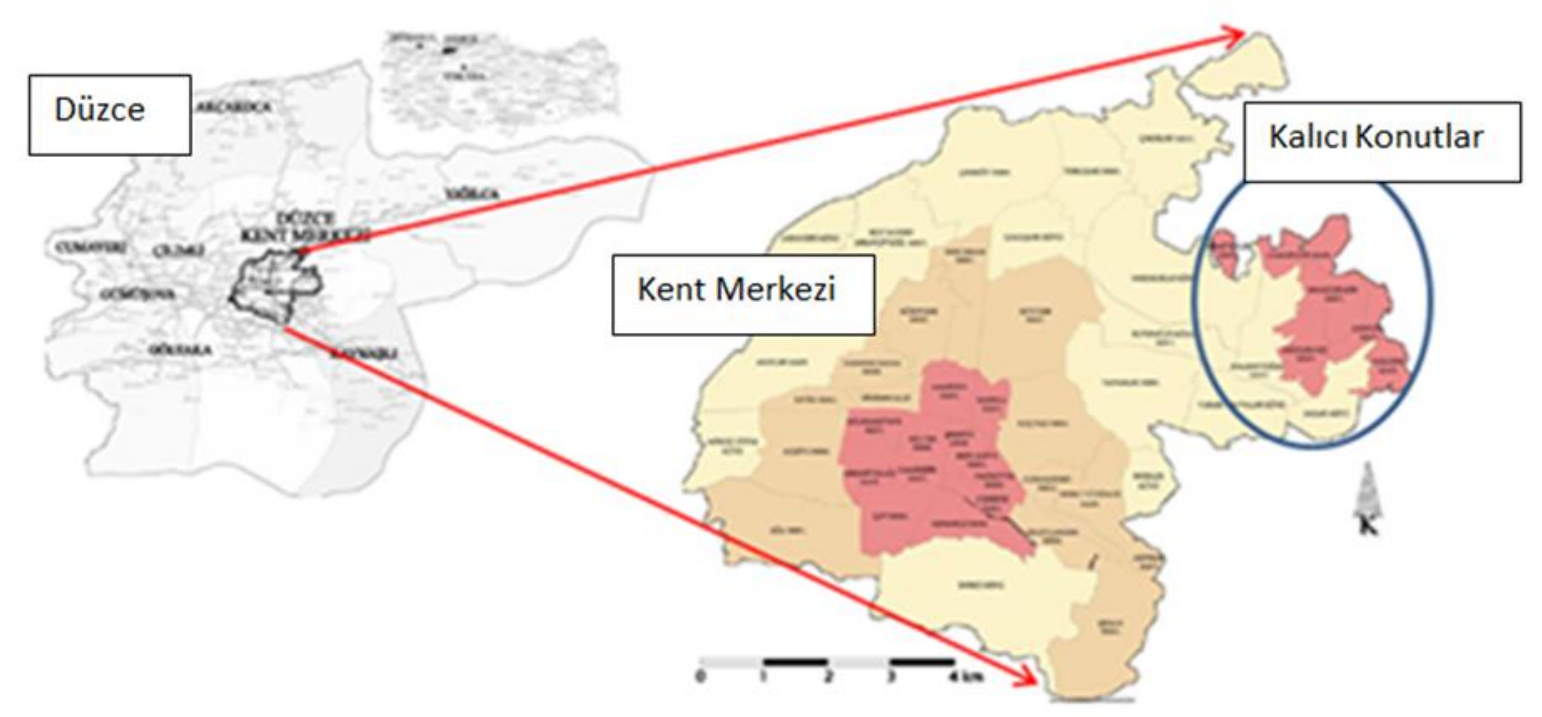

Kaynak: (Ö.Yerli $2016^{10}$, Ö.Yerli ve Z.Demir 2016 $6^{11}$, Ö.Yerli ve Z.Demir 2015 $5^{12}$, Ö.Yerli 2012 ${ }^{13}$ )

Şekil 1. Kalıcı Konutlar Bölgesi Konumu

Çalışma alanında içeresinde bulunan ilköğretim, ortaöğretim ve lise bahçelerinde spor alanları yer alan, sadece okulun öğrencileri tarafından devamlı olarak kullanıldığından her daim halkın kullanımına sunulmadığı için değerlendirmeye alınmamıştır.

\section{BULGULAR ve TARTISMA}

Düzce il merkezi nüfusu, merkez ilçe ve merkez ilçeye bağlı belde ve köyler ile birlikte, 31 Aralık 2017 tarihli ADNKS (Adrese dayalı nüfus kayıt sistemi) nüfus sayımına göre; \%49,99'u kadın, \%50,01'i erkektir. Toplam nüfus 377.610 kişiden oluşmaktadır.

Düzce il merkez ilçe kalıcı konutlar bölgesinde merkez ilçeye bağlı 6 adet mahalle bulunmaktadır. Bu mahallerde nüfus 31 Aralık 2017 tarihli ADNKS (Adrese dayalı nüfus kayıt sistemi) nüfus sayım sonuçlarına göre; \%52,59 'u kadın, \%47,41'i erkektir. Çalışma alanındaki nüfus toplam 23.219 kişiden oluşmaktadır (Tablo 4).

Tablo 4. Düzce ili merkez ilçeye bağglı kalıcı konutlara ait mahallelerde Nüfus (31 Aralık 2017 tarihli ADNKS).

\begin{tabular}{cccc}
$\begin{array}{c}\text { Düzce il merkez ilçeye bağlı kalıcı } \\
\text { konutlara ait mahalleler }\end{array}$ & Kadın & Erkek & Nüfus \\
\hline Bahçelievler Mahallesi & 2.433 & 2.237 & 4.670 \\
\hline Çamlı evler Mahallesi & 1.932 & 1.800 & 3.732 \\
\hline Demet evler Mahallesi & 1.240 & 1.164 & 2.404 \\
\hline Esentepe Mahallesi & 1.868 & 1.800 & 3.668 \\
\hline Güzelbahçe Mahallesi & 3.342 & 2.692 & 6.034 \\
\hline Yeşiltepe Mahallesi & 1.397 & 1.314 & 2.711 \\
\hline Toplam nüfus & $\mathbf{1 2 . 2 1 2}$ & $\mathbf{1 1 . 0 0 7}$ & $\mathbf{2 3 . 2 1 9}$
\end{tabular}

Tablo5'te bakıldığında çalışma alanında standartlara uygun yeşil alan miktarı en az $232.190 \mathrm{~m}^{2}$ 'lik alana ihtiyaç duyulmaktadır. Mahalle bazında değerlendirmede en fazla ihtiyaç duyulan yeșil alan miktarı $60.340 \mathrm{~m}^{2}$ 'lik alanla Güzelbahçe Mahallesi iken en az ise $24.040 \mathrm{~m}^{2}$ 'lik alanla Demetevler mahallesinde yeşil alan ihtiyaç duyulmaktadır. 
Tablo 5. Kalıcı konutlara ait mahallelerde Standartlara Uygun İhtiyaç Duyulan Yeşil Alan Miktarı

\begin{tabular}{cccc}
$\begin{array}{c}\text { Kalıcı Konutlara ait } \\
\text { mahalleler }\end{array}$ & Nüfus & $\begin{array}{c}\text { Tablo 1 Türkiye'de } \\
\text { Yeşil Alan Strandartı }\end{array}$ & $\begin{array}{c}\text { Standartlart Yeşil } \\
\text { Alan Miktarı }\end{array}$ \\
\hline Bahçelievler Mahallesi & 4.670 & $10 \mathrm{~m}^{2}$ & 46.700 \\
\hline Çamlı evler Mahallesi & 3.732 & $10 \mathrm{~m}^{2}$ & 37.320 \\
\hline Demet evler Mahallesi & 2.404 & $10 \mathrm{~m}^{2}$ & 24.040 \\
\hline Esentepe Mahallesi & 3.668 & $10 \mathrm{~m}^{2}$ & 36.680 \\
\hline Güzelbahçe Mahallesi & 6.034 & $10 \mathrm{~m}^{2}$ & 60.340 \\
\hline Yeşiltepe Mahallesi & 2.711 & $10 \mathrm{~m}^{2}$ & 27.110 \\
\hline Toplam & 23.219 & $10 \mathrm{~m}^{2}$ & $\mathbf{2 3 2 . 1 9 0}$
\end{tabular}

Tablo 6'da bakıldığında çalışma alanlarının yeşil alanların yeterli büyüklüğe uygun olduğu tespit edilmiştir.

Tablo 6. Kalıcı konutlara ait mahallelerde Standartlara Uygun İhtiyaç Duyulan Yeşil Alan Miktarı

\begin{tabular}{|c|c|c|c|}
\hline $\begin{array}{c}\text { Düzce il merkez ilçeye } \\
\text { bağlı kalıcı konutlara ait } \\
\text { mahalleler }\end{array}$ & $\begin{array}{l}\text { Standartlara Uygun } \\
\text { Olması Gereken Yeşil } \\
\text { Alan Miktarı }\left(\mathbf{m}^{2}\right)\end{array}$ & $\begin{array}{c}\text { Çalışma Alanında } \\
\text { Bulunan Yeşil Alan } \\
\text { Miktarı(m²) }\end{array}$ & $\begin{array}{c}\text { Yeşil alanların } \\
\text { Uygunluk Durumu } \\
\text { (Uygun /Uygun Değil) }\end{array}$ \\
\hline Bahçelievler Mahallesi & 46.700 & $183.843,81$ & Uygun \\
\hline Çamlı evler Mahallesi & 37.320 & $169.851,36$ & Uygun \\
\hline Demet evler Mahallesi & 24.040 & $61.577,42$ & Uygun \\
\hline Esentepe Mahallesi & 36.680 & $80.286,47$ & Uygun \\
\hline Güzelbahçe Mahallesi & 60.340 & $76.085,10$ & Uygun \\
\hline Yeşiltepe Mahallesi & 27.110 & 90334,41 & Uygun \\
\hline Toplam & 232.190 & 661.978,57 & Uygun \\
\hline
\end{tabular}

Tablo 7'de bakıldığında çalışma alanında standartlara uygun spor alan miktarı en az $69.657 \mathrm{~m}^{2}$ 'lik alana ihtiyaç duyulmaktadır. Mahalle bazında değerlendirmede en fazla ihtiyaç duyulan spor alan miktarı $14.010 \mathrm{~m}^{2}$ 'lik alanla Bahçelievler Mahallesi iken en az ise $7.212 \mathrm{~m}^{2}$ 'lik alanla Demetevler mahallesinde yeşil alan ihtiyaç duyulmaktadır.

Tablo 7. Kalıcı konutlara ait mahallelerde Standartlara Uygun İhtiyaç Duyulan Spor Alan Miktarı

\begin{tabular}{cccc}
$\begin{array}{c}\text { Düzce il merkez ilçeye bağlı } \\
\text { kalıcı konutlara ait mahalleler }\end{array}$ & Nüfus & $\begin{array}{c}\text { Tablo 1 Türkiye'de } \\
\text { Spor Alanı Standarttı }\end{array}$ & $\begin{array}{c}\text { Standartlara Uygun Olması } \\
\text { Gereken Spor Alan Miktarı }\end{array}$ \\
\hline Bahçelievler Mahallesi & 4.670 & $3 \mathrm{~m}^{2}$ & 14.010 \\
\hline Çamlı evler Mahallesi & 3.732 & $3 \mathrm{~m}^{2}$ & 11.196 \\
\hline Demet evler Mahallesi & 2.404 & 3.212 \\
\hline Esentepe Mahallesi & 3.668 & $3 \mathrm{~m}^{2}$ & 11.004 \\
\hline Güzelbahçe Mahallesi & 6.034 & $3 \mathrm{~m}^{2}$ & 18.102 \\
\hline Yeşiltepe Mahallesi & 2.711 & $3 \mathrm{~m}^{2}$ & 8.133 \\
\hline Toplam & $\mathbf{2 3 . 2 1 9}$ & $\mathbf{3} \mathbf{~ m}^{\mathbf{2}}$ & $\mathbf{6 9 . 6 5 7}$
\end{tabular}

Tablo 8'de bakıldığında çalışma alanlarının spor alanların yeterli büyüklüğe uygun olmadığı tespit edilmiştir.

Tablo 8. Kalıcı konutlara ait mahallelerde Standartlara Uygun İhtiyaç Duyulan Spor Alan Miktarı

\begin{tabular}{cccc}
$\begin{array}{c}\text { Düzce il merkez ilçeye bağlı } \\
\text { kalıcı konutlara ait mahalleler }\end{array}$ & $\begin{array}{c}\text { Standartlara Uygun } \\
\text { Olması Gereken } \\
\text { Spor Alan Miktarı }\end{array}$ & $\begin{array}{c}\text { Çalışma Alanında } \\
\text { bulunan Spor } \\
\left.\text { Alan Miktarı(m } \mathbf{m}^{\mathbf{2}}\right)\end{array}$ & $\begin{array}{c}\text { Spor alanların Uygunluk } \\
\text { Durumu (Uygun/Uygun } \\
\text { Değil) }\end{array}$ \\
\hline Bahçelievler Mahallesi & 14.010 & 4.980 & Uygun Değil \\
\hline Çamlı evler Mahallesi & 11.196 & 2.320 & Uygun Değil \\
\hline Demet evler Mahallesi & 7.212 & 4.216 & Uygun Değil \\
\hline Esentepe Mahallesi & 11.004 & 710 & Uygun Değil \\
\hline Güzelbahçe Mahallesi & 18.102 & 1.370 & Uygun Değil \\
\hline Yeşiltepe Mahallesi & 8.133 & 1.753 & Uygun Değil \\
\hline Toplam & $\mathbf{6 9 . 6 5 7}$ & $\mathbf{1 5 . 3 4 9}$ & Uygun Değil
\end{tabular}




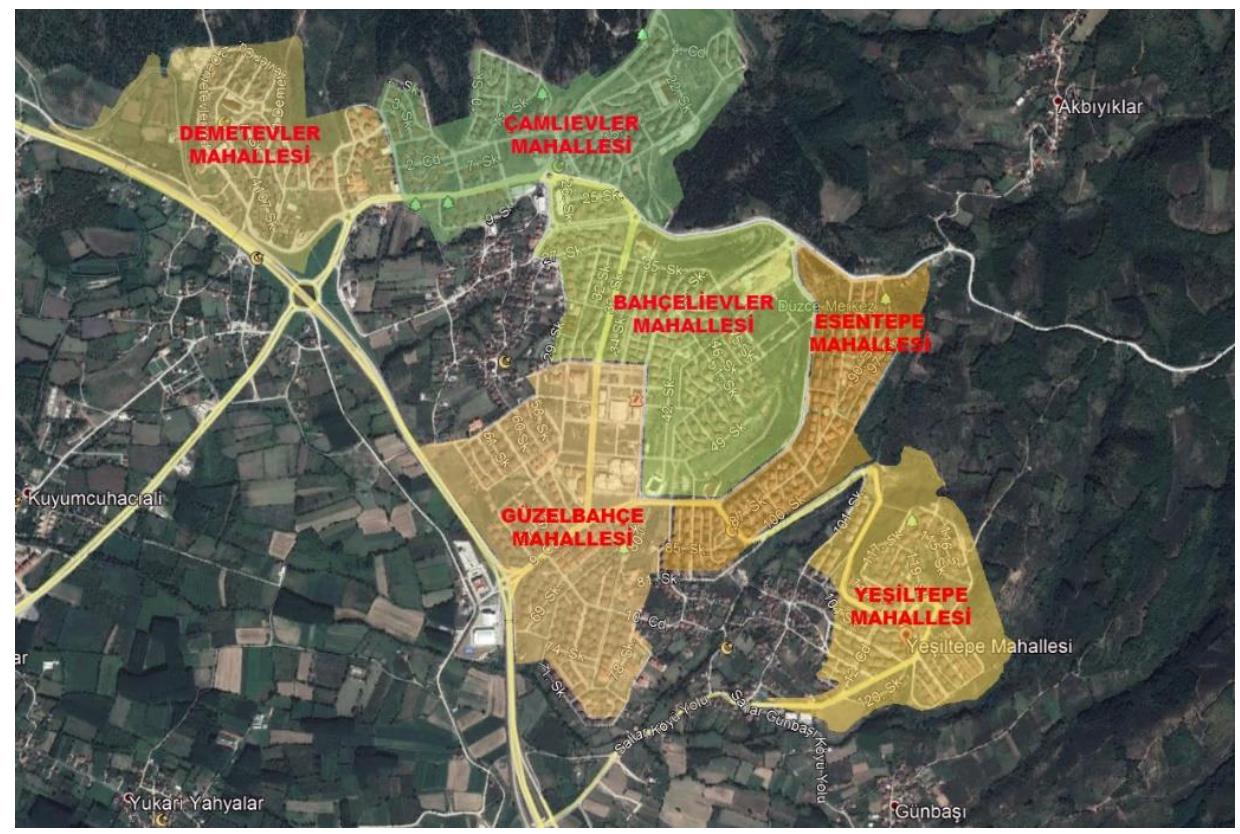

Şekil 2. Çalışma alanında yer alan mahaller

Tablo 9'da görüldüğü gibi çalışma alanı içerisinde futbol sahası 5 adet, basketbol sahası 6 adet, voleybol sahası 2 adet, güreş alanı 1 adet, çok amaçlı spor alanı2 adet ve fitness alanı 15 adet yer almaktadır. Çalışma alanında tenis sahası bulunmamaktadır. Spor alanları sayısı bakımından 9 adet alan Demetevleri mahallesinde olmasına rağmen alansal büyüklük bakımından en fazla spor alanı $4980 \mathrm{~m}^{2}$ ile Bahçelievler mahallesindedir. Spor alanlarının sayısı ve alansal büyüklük en az Esentepe mahallesindedir. Spor alanlarını mahalleler içerisindeki konumları Şekil 3’te görülmektedir.

Tablo 9. Düzce ili merkez ilçeye bağlı kalıcı konutlara ait mahallelerde spor alanları

Mahallelerdeki Mevcut Spor Alan Sayısı ve Alanı

\begin{tabular}{|c|c|c|c|c|c|c|}
\hline \multirow[b]{2}{*}{ Spor Alanı } & \multicolumn{6}{|c|}{ Mahallelerdeki Mevcut Spor Alan Sayısı ve Alanı } \\
\hline & $\begin{array}{c}\text { Bahçelievler } \\
\text { Mahallesi }\end{array}$ & $\begin{array}{l}\text { Çamlıevler } \\
\text { Mahallesi }\end{array}$ & $\begin{array}{c}\text { Demetevler } \\
\text { Mahallesi }\end{array}$ & $\begin{array}{l}\text { Esentepe } \\
\text { Mahallesi }\end{array}$ & $\begin{array}{c}\text { Güzelbahçe } \\
\text { Mahallesi }\end{array}$ & $\begin{array}{c}\text { YeşiltepeM } \\
\text { ahallesi }\end{array}$ \\
\hline Futbol Sahası & - & $1\left(1500 \mathrm{~m}^{2}\right)$ & $2\left(1771 \mathrm{~m}^{2}\right)$ & - & $1\left(1170 \mathrm{~m}^{2}\right)$ & $1\left(903 \mathrm{~m}^{2}\right)$ \\
\hline $\begin{array}{c}\text { Basketbol } \\
\text { Sahas1 }\end{array}$ & $1\left(420 \mathrm{~m}^{2}\right)$ & $1\left(420 \mathrm{~m}^{2}\right)$ & $1\left(450 \mathrm{~m}^{2}\right)$ & $1\left(400 \mathrm{~m}^{2}\right)$ & - & $2\left(840 \mathrm{~m}^{2}\right)$ \\
\hline $\begin{array}{c}\text { Voleybol } \\
\text { Sahası }\end{array}$ & $1\left(450 \mathrm{~m}^{2}\right)$ & - & $1\left(450 \mathrm{~m}^{2}\right)$ & - & - & - \\
\hline $\begin{array}{c}\text { Tek Potalı } \\
\text { Basketbol } \\
\text { Sahası } \\
\end{array}$ & $1\left(210 \mathrm{~m}^{2}\right)$ & - & - & $1\left(210 \mathrm{~m}^{2}\right)$ & - & $1\left(110 \mathrm{~m}^{2}\right)$ \\
\hline Fitness Alanı & $3\left(300 \mathrm{~m}^{2}\right)$ & $4\left(400 \mathrm{~m}^{2}\right)$ & $3\left(300 \mathrm{~m}^{2}\right)$ & $1\left(100 \mathrm{~m}^{2}\right)$ & $2\left(200 \mathrm{~m}^{2}\right)$ & $2\left(200 \mathrm{~m}^{2}\right)$ \\
\hline Güreş Alanı & $1\left(3600 \mathrm{~m}^{2}\right)$ & - & - & - & - & - \\
\hline $\begin{array}{c}\text { Çok Amaçlı } \\
\text { Sahası }\end{array}$ & $\mathrm{S}_{2}$ & - & $2\left(1245 \mathrm{~m}^{2}\right)$ & - & - & - \\
\hline $\begin{array}{l}\text { Toplam } \\
\text { miktar }\end{array}$ & $7\left(4980 \mathrm{~m}^{2}\right)$ & $6\left(2320 \mathrm{~m}^{2}\right)$ & $9\left(4216 \mathrm{~m}^{2}\right)$ & $2\left(710 \mathrm{~m}^{2}\right)$ & $3\left(1370 \mathrm{~m}^{2}\right)$ & $6\left(1753 \mathrm{~m}^{2}\right)$ \\
\hline
\end{tabular}




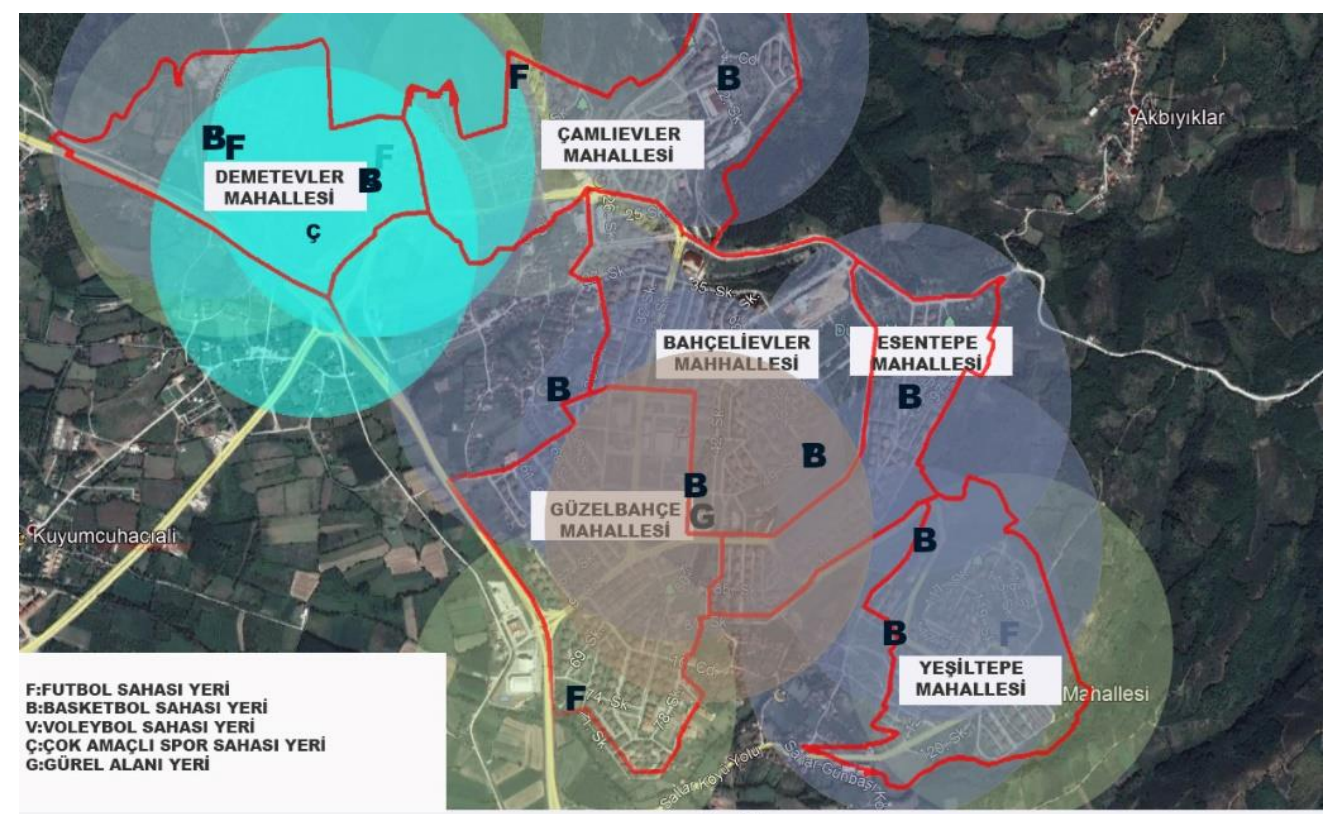

NOT:ÇALIŞMA ALANINDA BULUNAN SPOR ALANLARIN KONUMU VE ULAŞILABiLIRLIGi

Şekil 3. Çalışma alanında yer alan spor alanlarının konumları ve ulaşılabilirliği

Tablo 10. Düzce İli Merkez ilçeye bağlı kalıcı konutlara ait açık yeşil alanı, park alanı ve spor alanı

\begin{tabular}{|c|c|c|c|c|c|c|c|}
\hline $\begin{array}{c}\text { Çalışma } \\
\text { Alanında } \\
\text { Yer Alan } \\
\text { Mahalleler }\end{array}$ & Nüfus & $\begin{array}{c}\text { Açık Yeşil } \\
\text { Alan } \\
\left(m^{2}\right)\end{array}$ & $\begin{array}{c}\text { Park } \\
\text { Alanı } \\
\left(m^{2}\right)\end{array}$ & $\begin{array}{c}\text { Spor } \\
\text { Alanı } \\
\left(m^{2}\right)\end{array}$ & $\begin{array}{c}\text { Kişi } \\
\text { Başına } \\
\text { Düşen Açık } \\
\text { ve Yeşil } \\
\text { Alan } \\
\left(m^{2} / k i s ̧ i\right) \\
\end{array}$ & $\begin{array}{c}\text { Kişi Başına } \\
\text { Düşen Park } \\
\text { Alanı } \\
\left(\boldsymbol{m}^{2} / \mathrm{kissi}\right)\end{array}$ & $\begin{array}{c}\text { Kişi } \\
\text { Başina } \\
\text { Düşen } \\
\text { Spor } \\
\text { Alanı } \\
\left(\mathrm{m}^{2} / \mathrm{kişi} i\right) \\
\end{array}$ \\
\hline $\begin{array}{c}\text { Bahçelievler } \\
\text { Mahallesi }\end{array}$ & 4.670 & $183.843,81$ & $133.877,89$ & 4.980 & 39,37 & 28,67 & 1,07 \\
\hline $\begin{array}{l}\text { Çamlıevler } \\
\text { Mahallesi }\end{array}$ & 3.732 & $169.851,36$ & $133.989,45$ & 2.320 & 45,51 & 35,90 & 0,62 \\
\hline $\begin{array}{c}\text { Demetevler } \\
\text { Mahallesi }\end{array}$ & 2.404 & $61.577,42$ & $40.164,77$ & 4.216 & 25,62 & 16,71 & 1,75 \\
\hline $\begin{array}{l}\text { Esentepe } \\
\text { Mahallesi }\end{array}$ & 3.668 & $80.286,47$ & $50.489,43$ & 710 & 21,89 & 13,77 & 0,19 \\
\hline $\begin{array}{l}\text { Güzelbahçe } \\
\text { Mahallesi }\end{array}$ & 6.034 & $76.085,10$ & $60.091,75$ & 1.370 & 12,61 & 9,96 & 0,23 \\
\hline $\begin{array}{l}\text { Yeşiltepe } \\
\text { Mahallesi }\end{array}$ & 2.711 & 90334,41 & $90.334,41$ & 1.753 & 33,32 & 33,32 & 0,65 \\
\hline Toplam & 23.219 & $661.978,57$ & $508.947,70$ & 15.349 & 28,51 & 21,92 & 0,66 \\
\hline
\end{tabular}

Düzce Belediye Başkanlığı İmar ve Şehircilik Müdürlüğ̈̈’nden elde edilen verilere göre Kalıcı Konutlardaki açık yeşil alan 661.978,57 $\mathrm{m}^{2}$ alana sahip olup açık yeşil alan içerisinde bulunan park alanı $508.947,70 \mathrm{~m}^{2}$ olarak hesaplanmıştır. Diğer kalan alanlar ise Orman Alanı, Ağaçlandırma Alanı, Çocuk Bahçesi, Meydanlar, Piknik ve Rekreasyon Alanları, Mezarlıklar olarak belirtilmiştir.

Çalışma alanında kişi başına düşen yeşil alan miktarı $45,51 \mathrm{~m}^{2}$ ile en fazla Çamlıevler mahallesinde iken en az ise $12,61 \mathrm{~m}^{2}$ ile Güzelbahçe mahallesindedir. Türkiye'de açık yeşil alan standartlarına bakıldığında kişi başına $10 \mathrm{~m}^{2}$ 'dir.Böylece çalışma alanında yeşil alan miktarının en az olduğu mahalledeki yeşil alan miktarı Türkiye açık yeşil alan standartlarının üzerindedir. Ayrıca çalışma alanında kişi başına düşen yeşil alan miktarı $28,51 \mathrm{~m}^{2}$ olmakla beraber Türkiye yeşil alan standartların üstünde planlanmış olup kişi başına düşen açık yeşil alan miktarı yeterli büyüklüktedir. 
Tablo 9'da görüldüğü gibi çalışma alanında yer alan mahallerde yeterli büyüklükte park mevcuttur. Kişi başına düşen park büyüklüğü en fazla $35.90 \mathrm{~m}^{2}$ ile Çamlıevler mahallesinde en az $9.96 \mathrm{~m}^{2}$ ile Güzelbahçe mahallesindedir. Çalışma alanında kişi başına düşen park alan1 21,92m2'dir Görüldüğü üzere mevcut park büyüklükleri belirtilen normların üzerindedir.

Tablo 9 da görüldüğü gibi çalışma alanında yer alan mahallerde yeterli büyüklükte spor alanı bulunmamaktadır. Türkiye'de kişi başına düşen spor alanı büyüklüğü $3 \mathrm{~m}^{2}$ olması gerekirken en fazla kişi başına düşen spor alanı miktarı $1.75 \mathrm{~m}^{2}$ ile Demetevler mahallesinde, en az ise $0.19 \mathrm{~m}^{2}$ ile Esentepe mahallesindedir. Görüldüğü üzere çalışma alanı genelinde mevcut spor alanı büyüklükleri $0.66 \mathrm{~m}^{2}$ olup belirtilen normların altındadır.

Daire şeklide belirtilen alanlara spor alanlarına ulaşılabilirlik açısından değerlendirmeye tabi tutulmuştur. Spor alanı olan alan merkez olarak seçilmiş olup 600metre yarıçapında mesafe belirtilmiştir.600 metre belirtilmesindeki amaç ise Tablo2'de Çocuk bahçesindeki en uzak mesafe ele alınarak çocuklarında spor alanlarına ulaşabilir olduğuna kanaat getirmek için değerlendirildi. Diğer spor alanları içerisinde de bu mesafe baz alınmıştır.

Şekil 4'te çalışma alanında bulunan futbol sahaları ve bu sahalara ulaşılabilirlik haritası verilmiştir.

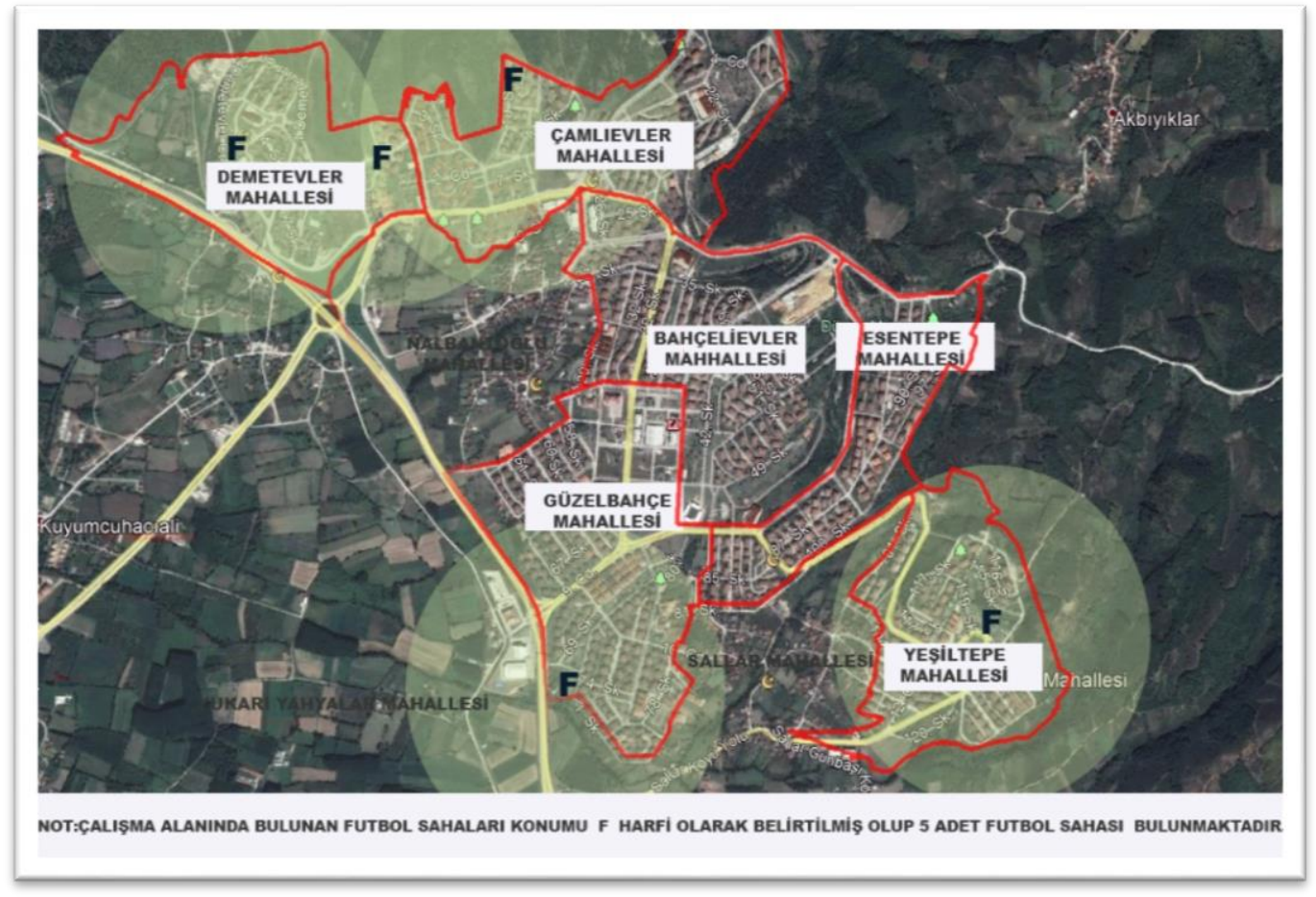

Şekil 4. Çalış̧ma alanında bulunan futbol sahaları ve ulaşılabilirliği

Kalıcı konutlara ait mahalle içerisinde bulunan futbol sahası Çamlı Evler mahallesinde 1adet, Demet evler mahallesinde 2adet, Güzelbahçe mahallesinde 1 adet ve Yeşil tepe mahallesinde 1adet olmak üzere toplam 5adet futbol sahası bulunmaktadır. Bunların Çamlıevler Mahallesi ve Güzelbahçe mahallesinde doğal çim zeminli olup diğerleri sentetik çim yüzeylidir. Çamlı evler mahallesi ve Güzelbahçe mahallesine standartlara uygun futbol saha yapılması gerekmektedir. Bahçelievler ve Esentepe mahallesinde futbol sahası bulunmamaktadır. Genel olarak futbol sahaları aydınlatma bakımından yetersiz ve bakımsızdır.

Şekil 5’te çalışma alanında bulunan basketbol sahaları ve bu sahalara ulaşılabilirlik haritası verilmiştir. 


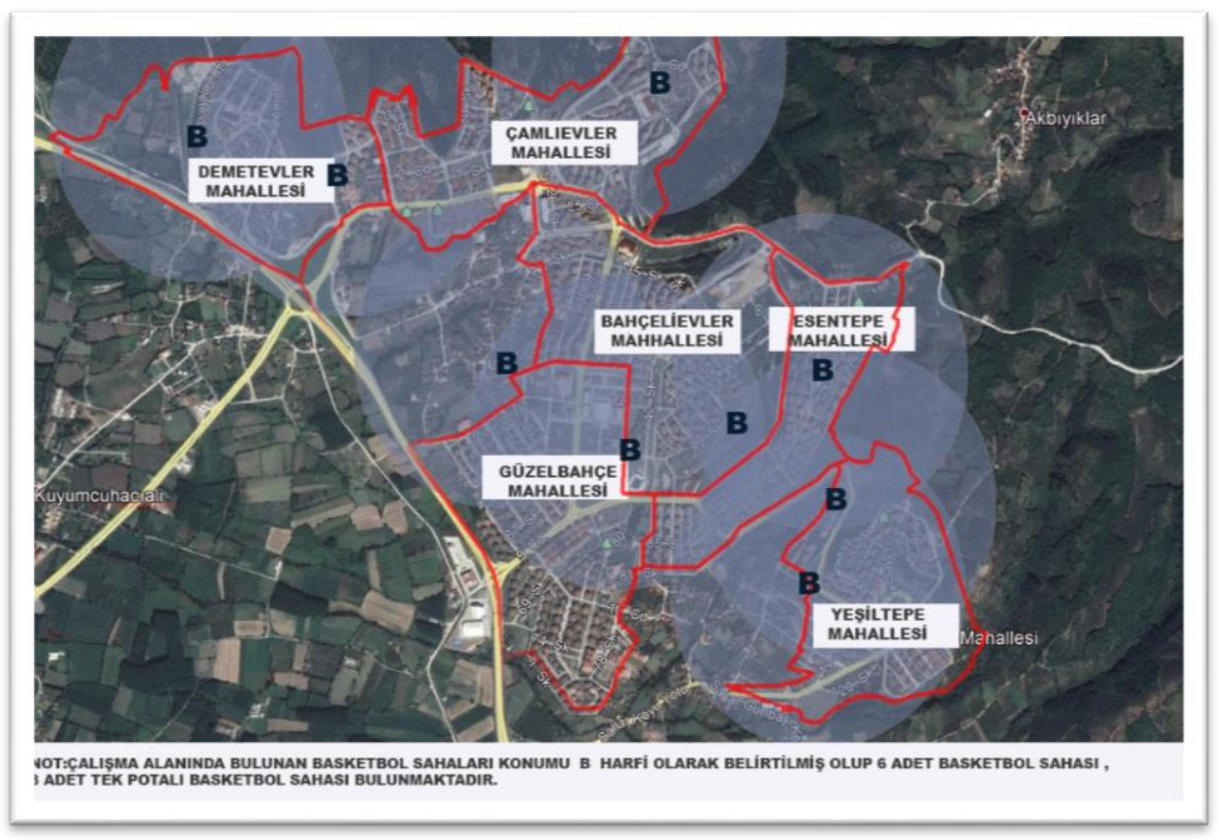

Şekil 5. Çalı̧̧ma alanında bulunan basketbol sahaları ve ulaşılabilirliği

Kalıcı konutlara ait mahalle içerisinde bulunan Basketbol sahası Bahçelievler Mahallesi 1 adet, Çamlievler mahallesinde 1 adet, Demet evler mahallesinde 1adet, Esen tepe mahallesi 1 adet ve Yeşiltepe mahallesinde 2 adet olmak üzere toplam 6 adet basketbol sahası bulunmaktadır. Tek potalı basketbol sahası ise Bahçelievler Mahallesi, Esentepe mahallesi ve Yeşiltepe mahallesi birer adet olmak üzere toplamda 3 adet bulunmaktadır. Güzelbahçe mahallesinde basketbol sahası bulunmamaktadır. Genel olarak basketbol sahalarında tel avlusu oldukça bakımsız olup basketbol potaları zarar görmüştür. Basketbol sahaların aydınlatma bakımından yetersiz ve bakımsızdır.

Şekil 6'da çalışma alanında bulunan voleybol sahaları ve bu sahalara ulaşılabilirlik haritası verilmiştir.

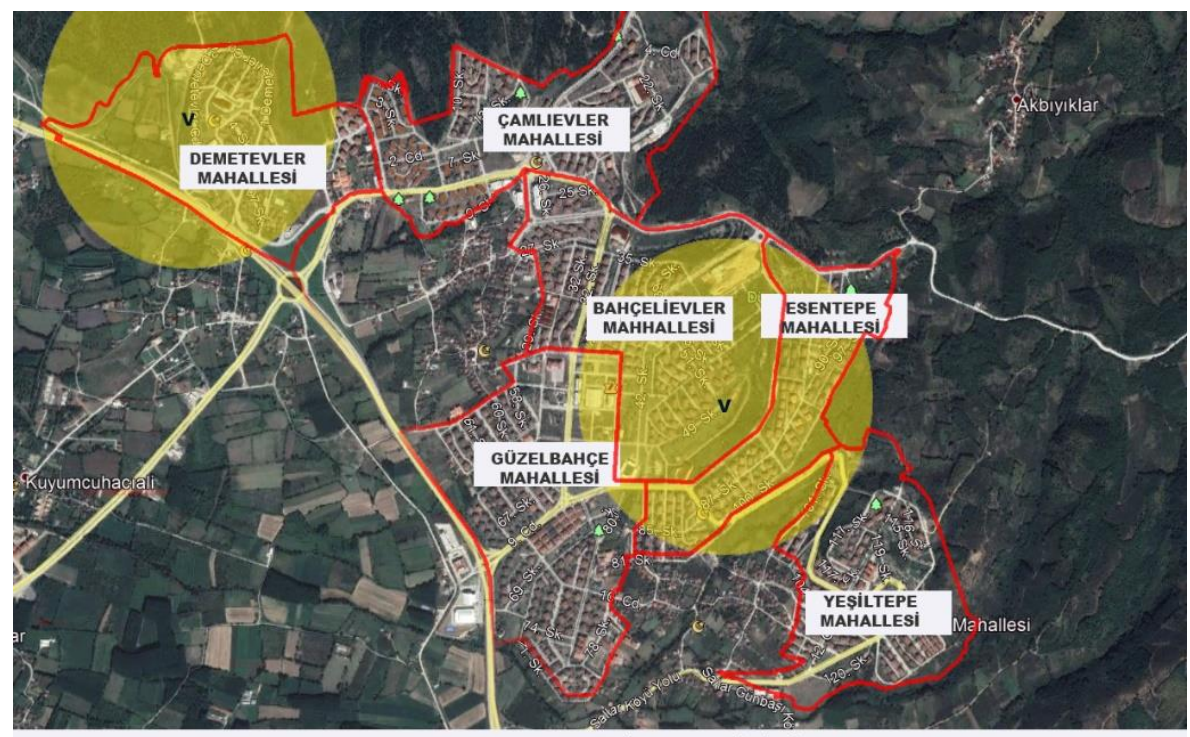

NOT:CALISSMA ALANINDA BULUNAN VOLEYBOL SAHALARI KONUMU V HARFI OLARAK BELIRTILMIŞ OLUP 2 ADET VOLEYBOL SAHASI

Şekil 6. Çalışma alanında bulunan voleybol sahaları ve ulaşılabilirliği

Kalıcı konutlara ait mahalle içerisinde bulunan voleybol sahası Bahçelievler Mahallesi 1 adet ve Demetevler mahallesinde 1 adet olmak üzere toplam 2 adet voleybol sahası bulunmaktadır. Genel olarak 
voleybol sahalarında tel avlusu oldukça bakımsız olup voleybol direkleri ve fileleri kullanılmaz hale getirilmiştir. Voleybol sahaların aydınlatma bakımından yetersiz ve bakımsızdır.

Şekil 7'de çalışma alanında bulunan çok amaçlı spor sahaları ve bu sahalara ulaşılabilirlik haritası verilmiştir.

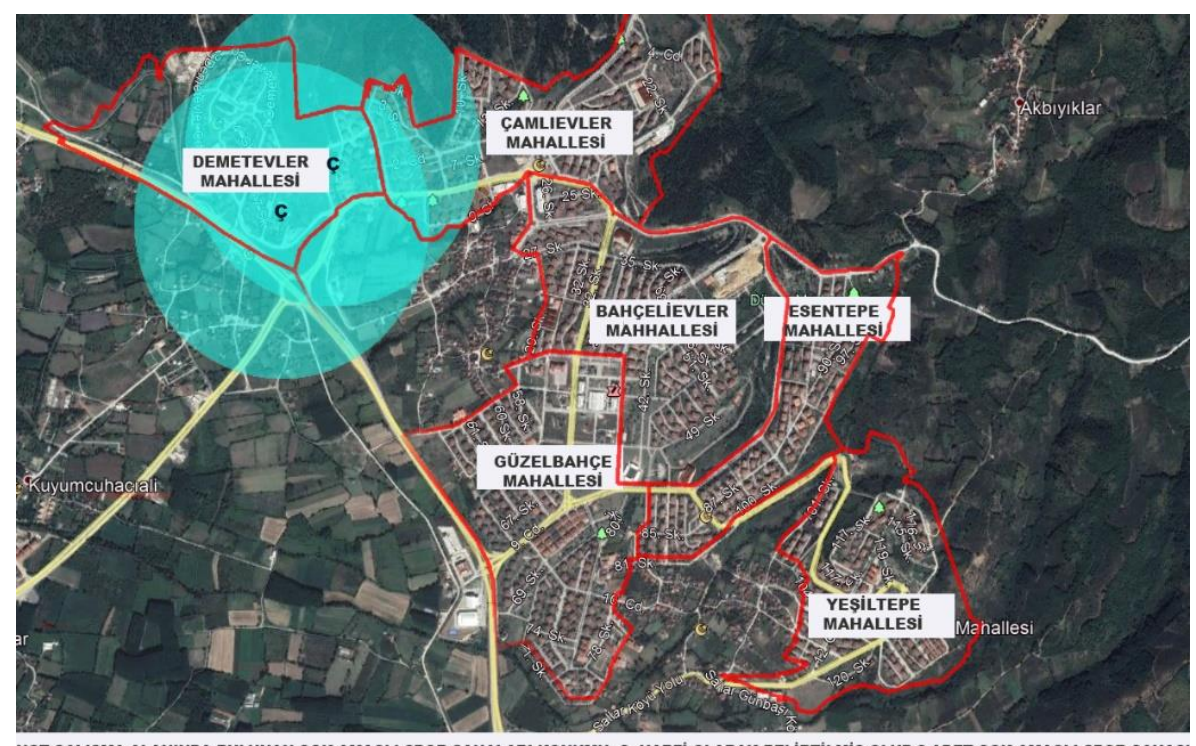

NOT:CGALISMA ALANINDA BULUNAN CCOK AMAÇLI SPOR SAHALARI KONUMU C HARFI OLARAK BELIRTILMIS OLUP 2 ADET COK AMAÇLI SPOR SAHAS BULUNMAKTADIR.

Şekil 7. Çalışma alanında bulunan çok amaçlı spor sahaları ve ulaşılabilirliği

Çalışma alanı içerisinde sadece Demetevler mahallesinde 2 adet çok amaçlı spor sahası bulunmamaktadır. Genel olarak çok amaçlı sahalarında tel avlusu oldukça bakımsızdır. Sahaların aydınlatma bakımından yetersiz ve bakımsızdır.

Şekil 8'de çalışma alanında bulunan güreş alanı ve bu alana ulaşılabilirlik haritası verilmiştir.

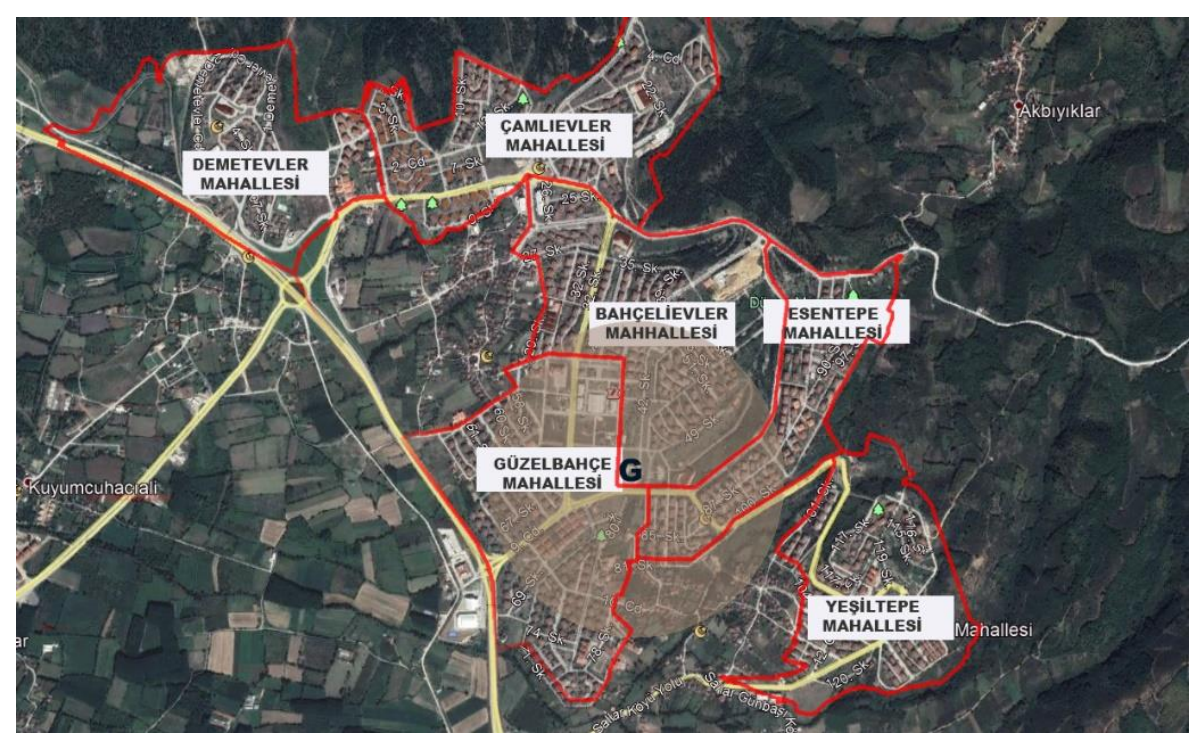

Şekil 8. Çalı̧̧ma alanında bulunan güreşs sahası ve ulaşılabilirliği

Çalışma alanı içerisinde Bahçelievler mahallesinde 1 adet güreş alanı bulunmaktadır. Genel olarak değerlendirildiğinde yılda 1 kez güreşçilerin hizmetinde olan alan başka aktivitelerde kullanılmamaktadır. 
Çalışma alanında yer alan spor alanları genel itibarı ile dengeli bir dağılım göstermemektedir. Spor alanlarına ulaşım kolay olmalıdır insanların spor alanına ulaşmak için en uygun yürüyüş mesafesi 8001600 metre uzaklıkta olması gerektiğini öne sürmüştür $[8,9]$.

Açık yeşil alanlar, park alanları ve spor alanları kent içerisinde boş alanlara rastgele yerleştirilmemelidir, Kentlerin imar planları yapılırken peyzaj mimarlarının görüşleri alınmalı aynı zamanda kenttin tümüne dengeli bir şekilde sağlanmalıdır. Kentte yaşayan insanların olabildiğince açık yeşil alan, park alanları ve spor alanlarından olabildiğince yararlanmalıdır.

Çalışma alanında futbol sahalarının dağılımına bakıldığında ise 6 adet mahallede 5 adet futbol sahası bulunmaktadır. Futbol sahası olmayan mahaller ise Bahçelievler ve Esentepe mahalleleridir. $\mathrm{Bu}$ bakımdan değerlendirildiğinde futbol sahalarının dağılımı dengeli değildir. Aynı zamanda spor alanlarına ulaşım kolay olmalıdır insanların spor alanına kolay ulaşabilmesi için en uygun yürüyüş mesafesi 800-1600 metre uzakl1kta olması öne sürüldügünden Bahçelievler ve Esentepe mahallesindeki insanların ulaşımı kolay olmamaktadır.

Çalışma alanında basketbol sahalarının dağılımına bakıldığında ise 6 adet mahallede 6 adet basketbol sahası ve 3 adet tek potalı basketbol sahası bulunmaktadır. Basketbol sahası olmayan mahalle ise Güzelbahçe mahallesidir. Bu bakımdan değerlendirildiğinde basketbol sahalarının dağılımı dengeli değildir. Aynı zamanda spor alanlarına ulaşım kolay olmalıdır insanların spor alanına kolay ulaşabilmesi için en uygun yürüyüş mesafesi 800-1600 metre uzaklıkta olması öne sürüldüğünden insanların ulaşımı kolay olmaktadır. Güzelbahçe mahallesinde basketbol sahası bulunmadığı halde ulaşımı değerlendiğinde Bahçelievler mahallesinde buluna sahadan yararlanabilir mesafesindedir.

Çalışma alanında voleybol sahalarının dağılımına bakıldığında ise 6 adet mahallede 2 adet voleybol sahası bulunmaktadır. Voleybol sahası olan mahaller ise Demetevler ve Bahçelievler mahalleleridir. $\mathrm{Bu}$ bakımdan değerlendirildiğinde voleybol sahalarının dağılımı dengeli değildir. Aynı zamanda spor alanlarına ulaşım kolay olmalıdır insanların spor alanına kolay ulaşabilmesi için en uygun yürüyüş mesafesi 800-1600 metre uzaklıkta olmas1 öne sürüldüğünden Çamlıevler Güzelbahçe ve Yeşiltepe mahallesindeki insanların ulaşımı kolay olmamaktadır. Bahçelievler ve Demetevler mahallesinin bir kısmı içinde ulaşımı kolay değildir. Voleybol sahası bulunmadığı Esentepe mahallesinde ulaşım kolay olmaktadır.

Çalışma alanında tenis sahalarının dağılımına bakıldığında ise 6 adet mahallede tenis sahası bulunmamaktadır.

Çalışma alanında güreş sahalarının dağılımına bakıldığında ise 6 adet mahallede 1 adet güreş sahası bulunmaktadır. Güreș sahası bulunan mahalle ise Bahçelievler mahallesidir. $\mathrm{Bu}$ bakımdan değerlendirildiğinde güreş sahalarının dağılımı dengeli değildir. Aynı zamanda spor alanlarına ulaşım kolay olmalıdır insanların spor alanına kolay ulaşabilmesi için en uygun yürüyüş mesafesi 800-1600 metre uzaklıkta olması öne sürüldüğünden Çamlıevler, Demetevler, Esentepe ve Yeşiltepe mahallesindeki insanların ulaşımı kolay olmamaktadır. Bahçelievler ve Güzelbahçe mahallelerin bir kısmı insanların ulaşımına kolay olamamaktadır.

Çalışma alanında çok amaçlı sahalarının dağılımına bakıldığında ise 6 adet mahallede 2 adet çok amaçlı sahası bulunmaktadır. Çok amaçlı spor sahasının birinde basketbol ve voleybol sahası bulunurken diğerinde futbol sahası ve basketbol birlikte oynanmaktadır. Çok amaçlı Sahası bulunan mahalle ise Demetevler mahallesidir. Bu bakımdan değerlendirildiğinde çok amaçlı spor sahalarının dağılımı dengeli değildir. Aynı zamanda spor alanlarına ulaşım kolay olmalıdır insanların spor alanına kolay ulaşabilmesi için en uygun yürüyüş mesafesi 800-1600 metre uzaklıkta olması öne sürüldügünden Çamlıevler, Bahçelievler, Güzelbahçe Esentepe ve Yeşiltepe mahallesindeki insanların ulaşımı kolay olmamaktadır. Demetevler mahallelerin insanların ulaşımına kolay sağlamaktadır. 


\section{IV.SONUC}

Çalışma alanın futbol sahas 6 adet, basketbol sahası 6 adet, tek potalı basketbol sahası 3 adet, voleybol sahası 2 adet, fitness alanı 15 adet, güreş alan 1 adet ve çok amaçlı spor sahası 2 adet mevcuttur. Tenis sahası bulunmamaktadır. Mevcut basketbol sahalarına içerisine voleybol sahası yapılarak çok amaçlı sahası oluşturulabilir.

Çalışma alanında Bahçelievler mahallesinde futbol sahası, tenis sahası ve aynı zamanda çok amaçlı spor sahası bulunmamaktadır. Çamlıevler mahallesinde ise voleybol sahası ve çok amaçlı spor sahası bulunmamaktadır. Esentepe mahallesinde futbol sahası, voleybol sahası ve çok amaçlı spor sahası bulunmamaktadır. Güzelbahçe mahallesinde basketbol sahası voleybol sahası ve tenis sahası bulunmamaktadır. Yeşiltepe mahallesinde voleybol sahası ve tenis sahası ve çok amaçlı spor sahası bulunmamaktadır. Çok amaçlı spor sahası sadece Demet evler mahallesinde bulunmaktadır.

Araştırma sonuçlarına göre, 23.219 nüfuslu çalışma alanında bulunan mahallelerde spor alanı kişi başına düşen miktar $0,66 \mathrm{~m}^{2}$ olarak hesaplanmıştır. Türkiye'de spor alanları standartlarına bakıldığında kişi başına düşen miktar $3 \mathrm{~m}^{2}$ 'dir. Böylece çalışma alanında kişi başına düşen miktar, olması gereken miktarın aşağı bir değer olduğundan yetersiz olduğu ortaya çıkmıştır. Çalışma alanında spor alanlarının toplamı 15,349 $\mathrm{m}^{2}$ 'dir. Çalışma alanında nüfusuna göre, gerekli spor alanı ise $69,657 \mathrm{~m}^{2}$ olarak hesaplanmıştır. Böylelikle Türkiye'de planlama standartlarına bakıldığında 54,308 $\mathrm{m}^{2}$ 'lik bir spor alanına ihtiyaç duyulmaktadır. Çalışma alanında 6 adet mahalle bulunduğundan çalışma alanını bütün olarak değerlendirmeye aldığımızda mahalle başına ortalama $9051.33 \mathrm{~m}^{2}$ alana ihtiyaç duyulmaktadır. $\mathrm{Bu}$ ihtiyacı karşılamak için çalışma alanında spor alanı içeren mahalle, semt ve kent parkı uygun yerlerde planlama yapıldığında gereksinim duyulan spor alanların ihtiyacını karşılanabilir. Park içerisinde yürüme yolları, bisiklet yolları, futbol sahası, basketbol sahası, voleybol sahası, tenis sahası, yüzme havuzları, fitness alanları, oryantiring alanları, patpaill alanları yapıldığında çalışma alanının bütününde değerlendirdiğimizde Türkiye standartlarına uygun spor alanları oluşturulabilir. Çalışma alanında yapılan incelemeler sonucunda bilhassa kamu kurumlarında bulunan spor alanlarının oldukça bakımsız olduğu gözlenmiştir. Aynı zamanda aydınlatma elamanlarının zarar gördüğü tespit edilmiştir. Aydınlatmanın yetersiz olduğu spor alanlarda mevcuttur.

Sonuç olarak, çalışma alanında planlanan spor alanlarının dengeli bir biçimde dağılmadığı gözlenmiştir. Aynı zamanda kenttin yeşil dokusuyla beraber gelişmesine, kentte bulunan insanların yaş grupları, eğitim seviyelerine ve beklentilerine önem verilmemiştir. Çalışma alanında bulunan spor alanlarının kapasite, büyüklükleri ve faaliyet alanları açısından yetersiz olduğu ortaya çıkmıştır.

Çalışma alanında yapılacak spor alanı planlamalarında, kentin yaş gruplarına, eğitim seviyelerine, kent insanın isteklerine ve planlama kriterlerine önem vermelidir. Kentte spor alanların mevcut durumu yerinde incelenerek kullanılabilir durumda olmalarına dikkat edilmelidir. Mahalle parkların yakınında yapılacak spor alanları ile bölge halkının sportif etkinliklere kolayca ulaşabilecekleri alanlar oluşturulmalıdır. Bu alanların oluşturulmasında hiç spor alanı olmayan mahalleden başlanarak bütün halkın spor ihtiyaçlarına karşılanabilir bir ortam oluşturulmalıdır.

Düzenli egzersizin sağlıklı bireylerin yetişmesi noktasında olumlu etkisi olduğu birçok araştırmacı tarafindan ortaya konulmuştur. Yaşadığımız çevrede daha sağlıklı bireylerin gelişmesi kendi aralarında sağlıklı sosyal ilişkileri olan bir toplum oluşturulması için çok büyük katkı sağlayan spor alanları hem mahalle halkının kolay ulaşabileceği yerlerde konumlanmalı hem de bu alanların düzenli bakımları yapılmalidir.

Alanda yer alan spor alanlarının en önemli amacı aynı değerli, tesirli ve verimli sosyal alanda yarar sağlamaktır. Tesislerdeki amaç sporu geniş kitlelere yaymaktır. Aynı zamanda toplumsal hizmet ve sosyal faydalar yaratmaktır. Bu amacı gerçekleştirmek için spor alanları kullanıcı gruplar kadar standartlara uygun bir şekilde çevrenin sağlığı, konforlu ve güvenliği korunması amaciyla yasal düzenlemelerle birlikte planlanmalıdır. Spor alanları engelliler dahil herkesin kolayca erişebileceği ve spor alanı sınırları içerisinde güvende olacağ 1 şekilde tasarlanmalıdır. Yeni yapılacak spor alanlarının 
sürdürülebilir olması, çoğalan nüfusun ihtiyaçlarını karşılayacak fiziksel büyümeye elverişli, en maksimum hizmetin en minimum maliyetle hizmetin oluşabilmesine imkân sağlamalıdır. Spor alanları için en uygun kuruluş yeri ile spor etkinliklerine katılım ilişkisi, hem tesisin cinsi hem de kapasitesinin belirlenmesinde önemli derecede rol oynamaktadır ve spor tesisin faaliyette bulunduğu yer spor alanının başarı açısından son derece önemlidir. Spor alanlarının sunduğu etkinlik ve imkânlardan yararlanmak isteyen halkın kolay, süratli ve güvenli biçimde spor alanlarına ulaşabilmesi spor alanının varlığını sürdürebilmesinde kolaylık sağlar.

\section{KAYNAKLAR}

[1] ～G.Akdoğan, "Doğa düzenleme,” Ders Notlarl, İstanbul. 1987.

[2] A. Özbilen., "Kentiçi Açık Alanlar ve Dağılımı, Tarihi Eserler ve Gelişen Yeni Yapılaşma," K.T.Ü. Orman Fakültesi, G. Y. N: 155, F.Y.N: 17, 1991.

[3] 3194 Sayılı İmar Kanunu ve İlgili Yönetmelikler, Bayındırlık ve İskan Bakanlığı Teknik Araştırma ve Uygulama Genel Müdürlüğü, Ankara, 2000.

[4] A.C. Yıldızcı, Kentsel yeşil alanlar, Ders Notları, İstanbul, 1987.

[5] M. Ersoy, Kentsel Alan Kullanım Normları, Ankara, Türkiye: ODTÜ Mimarlık Fakültesi Yayınları, 1994.

[6] H. Tümer, Rekreaktif Alan ve Tesisleri Ölçütleri, Turizm ve Tanıtma Bakanlığı Planlama Dairesi Başkanlığı, Ankara, 1976.

[7] A.C. Yıldızcı., "Açık Alan, Kentsel Doku ve Yeşil Doku Kavramları-Kentsel Peyzaj Planlama," Doçentlik Tezi, İstanbul Teknik Üniversitesi, İstanbul, Türkiye, 1982.

[8] K. Bakan, G. Konuk., Türkiye'de Kentsel Dış Mekanların Planlaması, Ankara, Türkiye: TÜBİTAK Yayın No:45, 1987.

[9] G.D. Türel, "Ankara kenti yeşil alanlarının kullanım etkinliklerinin bugünkü durumu ve yeterliliği için alınması gereken önlemler," Doktora Tezi, Peyzaj Mimarlığı, Fen Bilimleri Enstitüsü, Ankara Üniversitesi, Ankara, Türkiye, 1988.

[10] Ö. Yerli, "Düzce Kenti Yaya Bölgelerinin Gürültü Farklarının İncelenmesi," Kastamonu Üniversitesi Orman Fakültesi Dergisi, c. 16 s. 1, ss. 225-238, DOI: 10.17475/kujff.09619, 2016.

[11] Ö. Yerli, Z. Demir, "Relation Between Urban Land Uses And Noise A Case Study In Duzce Turkey," Oxidation Communication, c. 39 s. (I-II), ss. 732-745, 2016.

[12] Ö. Yerli, Z. Demir, 'Düzce Kenti Yerleşim Bölgelerindeki Gürültü Farkl1lıklarının İncelenmesi." Erciyes Üniversitesi Fen Bilimleri Enstitüsü Dergisi, c.31, s.1, ss. 32-42, 2015.

[13] Ö. Yerli, "Kentsel alan kullanım kaynaklı gürültünün Düzce kenti örneğinde irdelenmesi," Doktora tezi, Peyzaj Mimarlığı, Fen Bilimleri Enstitüsü, Düzce Üniversitesi, Düzce, Türkiye, 2012. 